\title{
Theoretical Postulates of Transport Disadvantage
}

\section{Teorijske postarke prometne marginaliziranosti}

This paper deals with the issue of transport disadvantage with the aim of giving a comprehensive overview of transport disadvantage theoretical postulates to provide a better understanding of the mentioned issue and to contribute to future research in the area of transport geography and transport planning. Transport disadvantage is a phenomenon that can affect both people and spaces, and occurs if mobility and accessibility are hindered, limited or disabled. The first part of this paper introduces definitions of transport disadvantage based on an extensive data collection and relevant scientific and professional literature. Next, various aspects of the impact of transport disadvantage on space and society are presented, while the last part of the paper describes the consequences of the impact of transport disadvantage. Transport disadvantage may also lead to social exclusion and, therefore, it should become an integral part of social policy and transport planning.

Key words: transport disadvantage, social exclusion, mobility, accessibility, transport geography
Rad se bavi problematikom prometne marginaliziranosti s ciljem opsežnijeg prikaza teorijskih postavki prometne marginaliziranosti kao doprinosa boljem razumijevanju navedene problematike i budućim istraživanjima u okviru prometne geografije i prometnog planiranja. Prometna marginaliziranost označuje pojavu koja može zahvatiti i ljude i prostore, a javlja se ako su mobilnost i dostupnost otežane, ograničene ili onemogućene. $\mathrm{Na}$ temelju ekstenzivnog prikupljanja i proučavanja relevantne znanstvene i stručne literature u prvom se dijelu rada predstavljaju definicije prometne marginaliziranosti, nakon toga se prikazuju razni aspekti utjecaja prometne marginaliziranosti na prostor i društvo, dok se na kraju rada opisuju posljedice prometne marginaliziranosti. Prometna marginaliziranost može dovesti i do socijalne isključenosti te bi zbog toga morala postati sastavni dio socijalne politike i prometnog planiranja.

Ključne riječi: prometna marginaliziranost, socijalna isključenost, mobilnost, dostupnost, prometna geografija 
HRVATSKI

GEOGRAFSKI

GLASNIK

78/1, 73-95 (2016.)

\section{Introduction}

The fundamental needs of every individual are performance of basic life functions and different activities while using various services. These needs must be an integral part of every country's social policy in setting the framework of "social justice". Such social policy must allow each individual at least the minimum participation in life activities to ensure there is no exclusion (Minogue, 1998). Foley (2004) considers that transport will play a major role in promoting social justice. Indeed, transport is considered as one of the key factors in people's lives that will influence accessibility and the ability to perform certain life functions. In this context, two elements will have a crucial role: one is mobility (physical and virtual) as the possibility and necessity of movement of the individual, the other is accessibility at the extent to which one may access certain services or activities. Appropriate mobility and accessibility are among the fundamental demands of today's globalised society (Hoyle and Knowles, 1998). However, mobility and accessibility could be hindered, limited or disabled and hence the usage of transport services could be threatened. In this case, a transport disadvantage will arise.

The issue of transport disadvantage has barely been discussed in Croatian scientific literature (only two papers have been published within this topic, see Gašparović, 2014; Gašparović and Jakovčić, 2014). There are only few papers directly discussing the issue of transport disadvantage. Therefore, the objective of this paper is to provide a theoretical overview of transport disadvantage, thus contributing to a better understanding of this issue and to future research in the area of transport geography and transport planning. This paper is the result of extensive work in reviewing the relevant scientific and professional literature with embedded thoughts and comments by the author on the issue of transport disadvantage. ${ }^{1}$ The first part of the paper, with an overview of previous research, tries to answer the question of what transport disadvantage is. The main part of the paper describes various aspects of the impact of transport disadvantage on the space and so-

\section{Uvod}

Obavljanje osnovnih životnih funkcija i različitih aktivnosti te korištenje pojedinim uslugama temeljne su potrebe svakog pojedinca. One moraju biti sastavni dio socijalne politike svake države u okviru provođenja „socijalne pravednosti”. Takva socijalna politika mora omogućiti svakom pojedincu barem minimum participiranja u životnim aktivnostima jer u protivnome može doći do njegove isključenosti (Minogue, 1998). Foley (2004) smatra kako će glavnu ulogu u promicanju socijalne pravednosti imati promet. Upravo se promet smatra jednim od temeljnih čimbenika u životima ljudi koji utječe na mogućnost obavljanja pojedinih životnih funkcija i pristup njima. U okviru toga dva će elementa imati presudnu ulogu: mobilnost (fizička i virtualna), kao mogućnost i potreba kretanja pojedinca, te dostupnost, kao opseg u okviru kojeg se može doći do određene usluge ili aktivnosti. Primjerena mobilnost i dostupnost osnovni su zahtjevi današnjega globaliziranog društva (Hoyle i Knowles, 1998). Ipak, mobilnost i dostupnost mogu biti otežane, ograničene ili onemogućene, što dovodi do ugrožavanja korištenja prometnim uslugama. U tom će slučaju nastupiti proces prometne marginaliziranosti.

Problematika prometne marginaliziranosti dosad gotovo uopće nije obrađivana u hrvatskoj znanstvenoj bibliografiji (tek dva znanstvena rada objavljena su na tu temu, vidi Gašparović, 2014; Gašparović i Jakovčić, 2014). Rijetki je se radovi tek posredno dotiču. Stoga je cilj ovog rada u širem opsegu prikazati teorijske postavke prometne marginaliziranosti kao doprinos boljem razumijevanju navedene problematike $\mathrm{i}$ budućim istraživanjima u okviru prometne geografije i prometnog planiranja. Rad je rezultat ekstenzivnog prikupljanja i proučavanja relevantne znanstvene i stručne literature i prožet je promišljanjima i komentarima autora glede problematike prometne marginaliziranosti. ${ }^{1} \mathrm{U}$ prvom se dijelu rada, uz pregled dosadašnjih istraživanja, pokušava odgovoriti na pitanje što je uopće prometna marginaliziranost. Središnji dio bavi se raznim aspektima utjecaja prometne marginaliziranosti na prostor i društvo (prometno

1 This article arose from the author's doctoral dissertation "Impact of transport disadvantage on everyday life of high school population of City of Zagreb". 1 Ovaj rad proizlazi iz autorove doktorske disertacije „Utjecaj prometne marginaliziranosti na svakodnevni život srednjoškolske populacije Grada Zagreba”. 
ciety (transport disadvantaged spaces and transport disadvantaged individuals i.e. social groups). The last part of the paper describes in detail the consequences of the impact of transport disadvantage.

\section{The notion of transport disadvantage}

Nowadays, transport plays a very important role in the organisation and the development of space in people's lives. It is an activity that represents transport of people, goods and energy and the transmission of information from one place to another (Black, 2003). Transport is a considerably spatial activity of which the essence is to connect certain areas or people. Although transport is a highly developed and complex activity, mainly due to the spatial aspect, it is the subject of geographical studies within the discipline of transport geography.

Transport is an essential element in people's everyday lives. Its function is to enable travelling from one place to another. The purpose of such travelling is mainly to meet life function and others, such as e.g. the function of work, the function of education, the need for recreation, and the like. If a person is unable to reach a place for conducting a certain function when necessary, or is limited in the choice of ways of getting to that point, then this person will be affected by a problem that can be defined as transport disadvantage. Finally, a person can get into a situation that will lead to problems related to employment, health, education etc., which may eventually lead to serious social disadvantages.

It has become a task and challenge for social policy makers and transport planners to provide sustainable transport. Since the basic characteristic of any social policy is implementation of social equality, particularly within the context of equal access to life opportunities and possibilities and participation in various forms of social activities, transport will play an important role in this process. Thereby, mobility and accessibility play crucial roles. Transport disadvantage will occur if hindered mobility and accessibility jeopardize the use of transport services. Thus, individuals, but also entire social groups, will not be able to participate in transport services (from the aspect of equity and equality) as does the rest of society (SEU, 2003; Lucas, 2004a; Knowles et al., marginalizirani prostori i prometno marginalizirani pojedinci odnosno socijalne skupine). Na kraju se detaljnije opisuju posljedice prometne marginaliziranosti.

\section{Pojam prometne marginaliziranosti}

Promet je prvorazredni fenomen današnjice koji ima sve veću ulogu u organizaciji i razvoju prostora te u životima ljudi. To je djelatnost koja predstavlja prijevoz ljudi, dobara i energije te prijenos informacija s jednoga mjesta na drugo (Black, 2003). Promet je izrazito prostorna djelatnost čija je suština povezivanje određenih prostora odnosno ljudi. Iako je promet izrazito razvijena i složena djelatnost, upravo zbog prostornog aspekta on je predmet proučavanja geografije, i to u okviru discipline prometne geografije.

Promet je neizostavan element u svakodnevnom životu ljudi. Njegova je funkcija omogućivanje putovanja ljudi s jednoga mjesta na drugo. Svrha takva putovanja uglavnom je zadovoljavanje životnih i drugih funkcija kao što su rad, obrazovanje, potreba za rekreacijom i slično. Ako osoba nije u mogućnosti doći na mjesto odvijanja određene funkcije kada je to potrebno ili je ograničena u izboru načina dolaska do tog mjesta, bit će zahvaćena problemom koji se može definirati kao prometna marginaliziranost. U konačnici se osoba može naći u situaciji koja će je dovesti do problema vezanih uz zapošljavanje, zdravstvo, obrazovanje i slično, što može rezultirati ozbiljnim socijalnim nedostacima.

Za donositelje socijalne politike i prometne planere zadatak je, ali i izazov omogućivanje održivog prometa na svim prostornim razinama. Budući da je osnovna značajka svake socijalne politike provođenje socijalne jednakosti, posebice u okviru jednakog pristupa životnim prilikama i mogućnostima te participiranju u različitim oblicima društvenih aktivnosti, promet će u tom procesu imati važnu ulogu. Mobilnost i dostupnost pritom su presudne. Prometna marginaliziranost nastupit će ako otežana mobilnost i dostupnost ugrožavaju korištenje prometnim uslugama. Tako pojedinci, ali i čitave društvene skupine neće moći participirati u prometnim uslugama (gledano s aspekta pravednosti i jednakosti) kao ostatak društva (SEU, 2003; Lucas,
Theoretical

Postulates of

Transport

Disadvantage

Teorijske postavke prometne marginaliziranosti 
GEOGRAFSKI

GLASNIK

78/1, 73-95 (2016.)
2008; Yigitcanlar et al., 2010; Rosier and McDonald, 2011).

With regard to transport disadvantage, it should be noted that this issue is extremely complex and multifaceted. The terminology used within this issue is not consistent. Transport disadvantage is being processed from various aspects and there is no unique definition of the process. Many authors consider its multidimensionality, but they differ in specifying the factors that affect it and which, eventually, determine the definition and scope of transport disadvantage. It should also be noted that in Croatian terminology there is no conventional term for transport disadvantage. ${ }^{2}$

The broadest definition of transport disadvantage defines it as a situation where a person cannot travel when and where he/she wants to without difficulties (Denmark, 1998). Two main elements can be distinguished from the definition: the desire for mobility, and certain difficulties. In line with that, individuals are not able to travel without difficulties that arise due to personal, legal, economic or social reasons.

Considering the importance of accessibility and mobility, Stanley and Stanley (2004) define transport disadvantage as a limitation in the use of transport options for certain reasons, restricting mobility and access to goods, services and interactions. The reasons that restrict mobility and accessibility can be the physical traits of an individual, gender, age, family status, employment status, financial status, ability to use a personal vehicle, language or education. Limited mobility and restricted accessibility to life activities can lead to social decline and social exclusion of individuals.

Although the car is an essential part of today's life, principally, public transport should be equally accessible to all. Therefore, transport disadvantage can be defined as the inability to use public transport due to lack of access to it (Battelino, 2009). 2004a; Knowles i dr., 2008; Yigitcanlar i dr., 2010; Rosier i McDonald, 2011).

Kada je riječ o prometnoj marginaliziranosti, valja istaknuti kako je ta problematika izrazito kompleksna i raznoznačna. Terminologija koja se u njoj upotrebljava nije konzistentna. Prometna marginaliziranost obrađuje se s različitih aspekata te ne postoji jedinstvena definicija tog procesa. Ono s čime se mnogi autori slažu jest njena multidimenzionalnost, ali se ipak razlikuju u navođenju čimbenika koji na nju utječu i koji u konačnici određuju samu njezinu definiciju i obuhvat. Također valja napomenuti kako $\mathrm{u}$ hrvatskoj znanstvenoj terminologiji ne postoji uvriježeni pojam za transport disadvantage u međunarodnoj terminologiji. Zbog teškoća u prevođenju tog pojma predlaže se termin prometna marginaliziranost, za koji se smatra kako najbolje opisuje spomenuti proces. ${ }^{2}$

U najširem smislu prometna marginaliziranost može se definirati kao situacija u kojoj osoba ne može putovati kada i kamo želi bez određenih poteškoća (Denmark, 1998). Iz definicije se mogu izdvojiti dva osnovna elementa: želja za kretanjem i poteškoće. Sukladno tome pojedine osobe nisu u mogućnosti putovati bez poteškoća koje se javljaju zbog osobnih, pravnih, gospodarskih ili socijalnih razloga.

S obzirom na važnost mobilnosti i dostupnosti Stanley i Stanley (2004) definiraju prometnu marginaliziranost kao uskraćivanje korištenja prometnim mogućnostima iz određenih razloga, što ograničava mobilnost i pristup dobrima, uslugama i interakcijama. Razlozi koji ograničavaju mobilnost i dostupnost mogu biti tjelesne osobine pojedinca, spol, starost, obiteljski status, zaposlenost, imovinsko stanje, mogućnost upotrebe osobnog automobila, jezik i obrazovanje. Uskraćena mobilnost i ograničena dostupnost životnih aktivnosti mogu dovesti i do socijalnog pada, odnosno socijalne isključenosti pojedinca.

\footnotetext{
2 It has been suggested that the term "prometna marginaliziranost" be used in Croatian scientific terminology.

2 Nakon promišljanja i predlaganja pojmova kao što su „prometna nedostatnost” (kao možda i najizravniji prijevod pojma transport disadvantage), "prometna isključenost”, „prometna uskraćenost” te „prometna prikraćenost”, odabran je pojam „prometna marginaliziranost”. Autor smatra kako je odabrani pojam najsličniji pojmu transport disadvantage jer označuje stanje u kojem se našao pojedinac ili socijalna skupina zbog nemogućnosti korištenja pojedinim prometnim uslugama ili njihove ograničenosti. Oni su dovedeni do margine ili ruba, ali taj rub odnosno marginu nisu prešli. Oni nisu isključeni (engl. exclusion), već su marginalizirani (u stanju su određenog nedostatka, ali ipak u većini slučajeva imaju neke solucije koje im više ili manje odgovaraju). Pojam prometna marginaliziranost može se upotrebljavati i u proučavanju prostora. On bi označivao prostor gdje razina prometnih usluga (npr. javni prijevoz, kvaliteta infrastrukture itd.) nije zadovoljavajuća, što bi značilo da je marginaliziran (prometno) u odnosu na druge prostore na kojima je razina prometnih usluga viša ili zadovoljavajuća.
} 
People who use a car may have certain difficulties in using it due to high fuel prices and car maintenance. With regard to this, transport disadvantage can be defined as a situation where a person is faced with difficulties in using private transport, and not just public transport (Currie et al., 2009).

Transport disadvantage appears at three levels. At the individual level (i.e. household level), there is a limitation in the mobility of the individual. At the local level, it depends on the accessibility to goods, services and interaction. At the metropolitan level, it occurs due to poorer connection of certain specific activity spaces that have significance for the wider metropolitan area (e.g. airports, universities, etc.) (Hurni, 2006).

The methodology of transport disadvantage determination will depend primarily on the goals and objective of the research. The methods used can be classified into four main groups.

Modelling in transportation planning finds its basis in a variety of mathematical models and algorithms and formulas that determine the characteristics of transportation structure and predict future movements. The bases of all the models used are gravity models and other related models (Dodson et al., 2004). Methods of spatial or socio-spatial analysis are reflected in the implementation of the geographic information system. Results are presented on a simple pictorial level and within the various multivariate analyses. Statistical methods are closely related to the modelling methods and socio-spatial analysis. They may vary from the very simple to the highly complex, such as, for example, regression analysis and factor analysis. Qualitative methods are extremely important in the determining of transport disadvantage. The most common form of data collecting is by using interviews or focus groups. Unlike quantitative methods, by applying qualitative methods, more direct, in-depth data on the basis of the views and experiences of people are obtained.

Transport disadvantage is a multidimensional concept because it combines the demographic, spatial and transport dimensions of studying the problem (Yigitcanlar et al., 2010). Due to this, transport disadvantage studies use a range of methods
Premda je automobil neizostavni dio današnjice, javni prijevoz načelno bi trebao biti dostupan svima. Stoga se prometna marginaliziranost može odrediti kao nemogućnost korištenja javnim prijevozom zbog nedostatnog pristupa prema njemu (Battelino, 2009).

Ljudi koji se koriste automobilom mogu pritom imati određene teškoće zbog visokih cijena goriva i održavanja automobila. S obzirom na to prometna marginaliziranost može se definirati i kao situacija u kojoj je osoba suočena s teškoćama u korištenju vlastitim prijevozom, a ne samo javnim (Currie i dr., 2009).

Prometna marginaliziranost javlja se na tri razine. $\mathrm{Na}$ individualnoj razini (odnosno razini kućanstva) javlja se kao ograničenje mobilnosti pojedinca, na lokalnoj razini ovisno o stupnju dostupnosti roba, usluga i interakcija, a na metropolitanskoj zbog lošije povezanosti prostora s nekim specifičnim aktivnostima koje imaju značenje za šire, metropolitansko područje (npr. zračna luka, sveučilište i slično) (Hurni, 2006).

Metodologija određivanja prometne marginaliziranosti ovisit će u prvom redu o ciljevima i predmetu istraživanja. Metode koje se upotrebljavaju mogu se svrstati u četiri glavne skupine.

Modeliranje u prometnom planiranju svoju osnovu pronalazi kod različitih matematičkih modela, odnosno algoritama te formula kojima se određuju obilježja prometnih struktura i predviđaju buduća kretanja. Osnova svih modela koji se upotrebljavaju jesu gravitacijski i drugi s njima povezani modeli (Dodson i dr., 2004). Metode prostorne, odnosno socioprostorne analize očituju se u primjeni geografskoga informacijskog sustava. Rezultati se prikazuju na jednostavnoj slikovnoj razini te u okviru različitih multivarijantnih analiza. Statističke metode usko su povezane s metodama modeliranja i socioprostornom analizom. One mogu varirati od vrlo jednostavnih pa do vrlo složenih, kao što je npr. regresijska analiza ili faktorska analiza. Kvalitativne metode izrazito su važne pri određivanju prometne marginaliziranosti. Podaci se najčešće prikupljaju pomoću intervjuiranja ili fokus grupa. $\mathrm{Za}$ razliku od kvantitativnih, primjenom kvalitativnih metoda dobivaju se izravniji, odnosno dubinski podaci na temelju stavova i iskustava ljudi.

Prometna marginaliziranost multidimenzionalni je koncept jer kombinira demografsku, prostornu i pro-
Theoretical

Postulates of

Transport

Disadvantage

Teorijske postavke prometne marginaliziranosti 
GEOGRAFSKI

GLASNIK

78/1, 73-95 (2016.) that are relatively difficult to classify in one of the above-mentioned groups. Transport disadvantage is closely related to mobility, accessibility, location of living and activities and the physical, social and psychological characteristics of the individual, so the methods for determining and measuring transport disadvantage will certainly be closely related to the mentioned factors. Therefore, methods used can be classified into a group of objective or subjective indicators. The objective indicators include the location and mobility based measures. Location based measures in transport disadvantage research of space include indicators such as travel time to specific activities, distance to the specific activities and the like (for example, used by Dijst, 1999; Gašparović, 2014). Mobility based measures refer to research such as determining the development of transport services in a certain area or owning a car (for example, used by Hine and Mitchell, 2003). As part of subjective indicators, determining of transport disadvantage of certain social groups should be pointed out. That is often carried out by applying qualitative research methods (such as focus groups), the method of self-reported measures (or self-reported difficulties), determining problems in accessing activities and the consequences ensuing from those and the like (for example, used by Currie and Delbosc, 2011a; Hurni, 2007; SEU, 2003; Gašparović, 2014; Gašparović and Jakovčić, 2014).

\section{Review of previous research}

Scientific research in the past often neglected the issue of mobility and accessibility. This issue did not get enough attention in the framework of social sciences (including geography). In recent years, however, mobility and accessibility have become a common topic in interdisciplinary research, emphasizing the existence and importance of the "mobility paradigm" (Knowles et al., 2008).

"Quantitative revolution" in the 1960s and early 1970s led to a series of erroneous decisions in transport planning. Transport planners were under the influence of growing auto-mobilisation, wanted to increase human mobility based on quantitative methods, not paying attention to the aspects of "specificity" and "subjectivity" that mobility and metnu dimenziju proučavanja problema (Yigitcanlar i dr., 2010). S obzirom na to pri njezinu istraživanju upotrebljava se čitav niz metoda koje je relativno teško uvrstiti u jednu od navedenih skupina. Prometna marginaliziranost usko je povezana s mobilnošću, dostupnošću, lokacijom življenja i aktivnosti te tjelesnim, društvenim i psihološkim karakteristikama pojedinca, zbog čega će metode za njezino određivanje i mjerenje svakako biti u uskoj vezi s navedenim čimbenicima. Stoga se upotrijebljene metode mogu svrstati u skupinu objektivnibili subjektivnib pokazatelja.U objektivne pokazatelje ubrajaju se lokacijski i mobilnošću uvjetovana mjerila. Lokacijski uvjetovana mjerila pri istraživanju prometne marginaliziranosti prostora uključuju pokazatelje kao što su vrijeme putovanja do određenih aktivnosti, udaljenost do određenih aktivnosti i slično (upotrebljavaju ih npr. Dijst, 1999; Gašparović, 2014). Mobilnošć urjetovana mjerila odnose se na istraživanja kao što su utvrđivanje razvijenosti prometnih usluga na nekom prostoru ili posjedovanje automobila (upotrebljavaju ih npr. Hine i Mitchell, 2003). U okviru subjektivnih pokazatelja valja istaknuti utvrdivanje prometne marginaliziranosti pojedinih socijalnih skupina, koje se često provodi primjenom kvalitativnih metoda istraživanja (npr. fokus grupe), metodom vlastite procjene utjecaja prometnih problema, određivanjem problema kod pristupanja aktivnostima kao i posljedicama koje iz toga proizlaze i slično (upotrebljavaju ih npr. Currie i Delbosc, 2011a; Hurni, 2007; SEU, 2003; Gašparović, 2014; Gašparović i Jakovčić, 2014).

\section{Pregled dosadašnjih istraživanja}

U prošlosti je problematika mobilnosti i dostupnosti u znanstvenim istraživanjima poprilično zanemarivana. Nije joj se posvećivala dovoljna pozornost ni u okviru društvenih znanosti ( $\mathrm{pa}$ ni geografije). Ipak, posljednjih se godina mobilnošću i dostupnošću često bave interdisciplinarna istraživanja, naglašavajući postojanje i važnost „paradigme mobilnosti" (Knowles i dr., 2008).

„Kvantitativna revolucija” iz 60-ih i početka 70ih godina 20. stoljeća uzrokovala je niz pogrešnih odluka u prometnom planiranju. $\mathrm{Na}$ temelju kvantitativnih metoda prometni su planeri pod utjecajem rastuće automobilizacije željeli povećati mobilnost ljudi ne obraćajući pozornost na aspekte „specifičnosti” i ,subjektivnosti” koje mobilnost i dostupnost 
accessibility contain. There was an improvement in mobility and accessibility of people who had access to a car, but the social groups that did not own a car or could not use it, were neglected. The use of qualitative methods (e.g. travel diaries and focus groups) contributed to increasing awareness of the need to provide a sufficient level of mobility and accessibility for all social groups and not only for those with access to a car. The focus is placed on studying transport demand and strengthening transport supply in terms of public transport, and pedestrian and cycling transport. The individual is placed at the centre of attention, while the research focus is shifted from the aggregated and general to the specific, with the aim of obtaining personal attitudes and problems of individuals and individual social groups with regards to transport (Hoyle and Knowles, 1998; Knowles et al., 2008). This led to an increase in the number of scientific papers on the subject of transport disadvantage. Though the majority of scientific papers have investigated transport disadvantage only partly or within some other issues (e.g. social exclusion), a number of studies has also engaged with transport disadvantage; the most important ones being included in this review. The issue of transport disadvantage is almost entirely addressed in foreign scientific bibliography, primarily in Australia and the United Kingdom.

A special contribution to the study of transport disadvantage in Australian and world scientific literature was given by Graham Currie and Alexa Delbosc. By studying the spatial differences in the transport disadvantage of Melbourne and its surrounding areas, they have recognized that the level of transport disadvantage increased with the distance from the centre of Melbourne and transport disadvantage had a greater impact on social exclusion and quality of life (Currie et al., 2009; Delbosc and Currie, 2011a; 2011b). Investigating the impact of social and psychological factors on transport disadvantage, Delbosc and Currie (2010; 2011c) found that residents of the peri-urban part of Melbourne had more transport problems than residents living closer to the city centre. Delbosc and Currie (2012) examined the impact of the family car number on the mobility of its members. In doing so, they found that families who are forced to own a car and have only one car and several adult members who use sadržavaju. Nastupilo je poboljšanje mobilnosti i dostupnosti ljudi koji imaju pristup automobilu, a zanemarene su skupine društva koje nemaju automobil ili se njime ne mogu koristiti. Upotreba kvalitativnih metoda (npr. dnevnici putovanja i fokus grupe) pridonijela je jačanju svijesti o potrebi postizanja i omogućivanja dostatne razine mobilnosti i dostupnosti za sve skupine društva, a ne samo za one koje imaju pristup automobilu. Fokus postaje proučavanje prometne potražnje i jačanje prometne ponude u javnom prijevozu, pješačkom i biciklističkom prometu. U središte se stavlja pojedinac, dok se težište istraživanja pomiče $s$ agregiranoga $\mathrm{i}$ općenitoga na specifično, pri čemu se žele ustanoviti osobni stavovi i problemi pojedinaca i pojedinih socijalnih skupina prema prometu (Hoyle i Knowles, 1998; Knowles i dr., 2008). Time raste broj znanstvenih radova na temu prometne marginaliziranosti. Iako se $u$ većini radova prometna marginaliziranost obrađuje samo djelomično ili u sastavu neke druge problematike (npr. socijalne isključenosti), niz radova izravno se bavi prometnom marginaliziranošću te će oni najznačajniji biti obuhvaćeni ovim pregledom. Problematika prometne marginaliziranosti gotovo je isključivo vezana uz inozemnu znanstvenu bibliografiju, i to ponajprije Australije i Ujedinjenoga Kraljevstva.

Poseban doprinos istraživanju prometne marginaliziranosti u australskoj, ali i svjetskoj znanstvenoj bibliografiji dali su Graham Currie i Alexa Delbosc. Proučavajući prostorne razlike u prometnoj marginaliziranosti Melbournea i njegove okolice, uočili su povećanje stupnja prometne marginaliziranosti s udaljavanjem od središta Melbournea te njezin utjecaj na socijalnu isključenost i kvalitetu života ljudi (Currie i dr., 2009; Delbosc i Currie, 2011a; 2011b). Istražujući utjecaj socijalnih i psiholoških čimbenika na prometnu marginaliziranost ljudi, Delbosc i Currie $(2010 ; 2011 c)$ ustanovili su kako stanovnici periurbanog dijela Melbournea imaju više prometnih problema nego stanovnici koji žive bliže gradskom središtu. Delbosc i Currie (2012) istraživali su i utjecaj broja automobila u obitelji na mobilnost njenih članova te ustvrdili kako obitelji koje su prisiljene posjedovati automobil te imaju jedan automobil i više odraslih članova koji se njime koriste, a ne mogu si priuštiti kupnju još jednog automobila, imaju više problema u obavljanju svakodnevnih aktivnosti u usporedbi s obiteljima koje posjeduju
Theoretical

Postulates of

Transport

Disadvantage

Teorijske postavke prometne marginaliziranosti 
GEOGRAFSKI

GLASNIK

78/1, 73-95 (2016.) it, and cannot afford to buy another car, have more problems in performing daily activities compared with families that have more cars. In addition, their social network was smaller and their subjective perception of life quality was lower. A comprehensive study on the transport issues faced by youth was conducted by Currie (2007). This study addressed the issues of youth and their growing desire for independence, and the lack of transport options that would allow them to meet this desire. They stressed that the problems of access to educational activities, possibilities of employment, leisure time activities and social interactions were most difficult for the youth living at the city periphery or the broader urban area, and in rural areas. Even if public transport is available, it does not necessarily meet the transport needs of the public. Hurni (2007) stressed the lack of correlation between the distribution of the public transport network in the western part of the city of Sydney and unemployed youth, who face problems such as the high price of transport, feelings of fear and insecurity while using transport, the issue of transport frequency, among others.

In the United Kingdom, Karen Lucas and Julian Hine made a considerably contribution to the study of the problems of transport disadvantage. Lucas (2004) pointed out that the problems of transport and transport disadvantage must become part of the social policy of each country since they can affect the social characteristics of people. Along with Kelly Clifton (2004), Lucas investigated the presence of transport inequality and problems that arise from it by comparing the United Kingdom and United States. Hine and Mitchell (2001; 2003) detected transport disadvantaged areas in Scotland and they also studied the impact of transport disadvantage on certain social groups, emphasizing that women are more affected by transport disadvantage then men. Hine and Scott (2000) linked transport disadvantage with the perception of safety and fear in transport, which affect mobility. They found that older people, women and members of ethnic minorities feel more fear in public transport then the rest of the population. Therefore, they use alternative solutions in transport (e.g. usage of a private car or taxi) or avoid travelling, which leads to problems in the organization of everyday life. više automobila. Također, njihova je socijalna mreža manja, kao i njihov subjektivni doživljaj kvalitete života. Sveobuhvatnu studiju o problemima s kojima se susreću mladi u prometu izradio je Currie (2007). Bavi se problemom mladih i njihovom rastućom željom za neovisnošću te nedostatkom prometnih mogućnosti kojima bi tu želju zadovoljili, ističući kako se s problemom pristupa obrazovnim aktivnostima, mogućnostima zapošljavanja, aktivnostima vezanim uz slobodno vrijeme i socijalnim interakcijama najteže nose mladi koji žive na rubu grada, odnosno u široj gradskoj regiji te u ruralnim prostorima. Iako je javni prijevoz omogućen, on ne mora nužno zadovoljavati prijevozne potrebe ljudi. Tako Hurni (2007) ističe nepodudarnost razvijenosti javnog prijevoza na prostoru zapadnog dijela Sydneya i nezaposlenih mladih ljudi koji imaju poteškoća zbog visoke cijene prijevozne karte, osjećaja straha i nesigurnosti pri korištenju prijevozom, frekvencije prometovanja i sl.

U Ujedinjenom Kraljevstvu proučavanju problematike prometne marginaliziranosti ponajviše su pridonijeli Karen Lucas i Julian Hine. Lucas (2004a) ističe kako problematika prometa i prometne marginaliziranosti mora postati dio socijalne politike svake države jer može utjecati na socijalne značajke ljudi. S Kelly Clifton (2004) proučavala je prisutnost prometne nejednakosti i probleme koji iz nje proizlaze uspoređujući Ujedinjeno Kraljevstvo i Sjedinjene Američke Države. Hine i Mitchell (2001; 2003) detektiraju prometno marginalizirane prostore u Škotskoj te proučavaju utjecaj prometne marginaliziranosti na život pojedinih skupina ljudi, naglašavajući kako su žene jače zahvaćene prometnom marginaliziranošću od muškaraca. Hine i Scott (2000) dovode u vezu prometnu marginaliziranost s percepcijom sigurnosti i straha u prometu, što će utjecati na mobilnost tih osoba. Ustanovili su kako stariji ljudi, žene i pripadnici etničkih manjina osjećaju veći strah u javnom prijevozu od ostatka populacije te zbog toga pribjegavaju drugim rješenjima u prijevozu (npr. korištenje osobnim vozilom ili taksijem) ili izbjegavaju putovanje, što dovodi do problema u organizaciji svakodnevnog života.

Iako se problematika prometne marginaliziranosti istražuje uglavnom u okviru gradskih prostora, 
Although the issue of transport disadvantage is explored mainly within the urban areas, a small part of the scientific work refers to rural areas. Thus, Kamruzzaman and Hine $(2011 ; 2012)$ investigated transport disadvantage of rural areas on the example of Northern Ireland.

Croatian scientific literature, addresses the issue of transport disadvantage within only two papers. Gašparović and Jakovčić (2014) examined gender differences within the impact of transport disadvantage on life of high school students of the City of Zagreb. The results implied stronger transport disadvantage of girls compared to boys, especially in the area of safety in public transport. Gašparović (2014) examined the impact of transport disadvantage on high school pupil education, noticing the impact of travel time (or location of residence) on their school performance. Concerning other scientific and professional literature, the influence of transport on the young people's lives has been examined exclusively in the context of traffic safety, but not from the perspective of transport disadvantage. Only a few papers have directly studied the issue of transport disadvantage. Šakaja and Višnić (2011) mentioned the lack of adequate transport infrastructure and public transport in the city of Karlovac, which hinders quality leisure time. Spevec (2011) considered accessibility and transport connections as a factor that influences the processes of migration and circulation of the population in the North-western Croatia.

\section{Transport disadvantaged spaces}

Characteristics of mobility and accessibility in a certain space will depend on the characteristics of the space and also on the personal characteristics of the population that lives in that space. Characteristics of space are the extent of accessible transport services in this space and the extent and location of activities that people want to access (Hurni, 2006). These characteristics can lead to transport disadvantage. Thus, the mobility of people will be affected by the lack of public transport in a space, its rare frequency, inability of people to afford transport services because of price, location of people in relation to transport services and required activities, and the like. manji dio znanstvenih radova proučava prometnu marginaliziranost $\mathrm{u}$ ruralnim prostorima. Tako se Kamruzzaman i Hine $(2011 ; 2012)$ bave prometnom marginaliziranošću ruralnog prostora na primjeru Sjeverne Irske.

U hrvatskoj znanstvenoj bibliografiji problematika prometne marginaliziranosti obrađena je u tek dva znanstvena rada. Gašparović i Jakovčić (2014) proučavaju spolne razlike pri utjecaju prometne marginaliziranosti na život srednjoškolaca Grada Zagreba, pri čemu uočavaju jaču prometnu marginaliziranost djevojaka u odnosu na mladiće, posebice u segmentu sigurnosti u javnome gradskom prijevozu. Gašparović (2014) proučava utjecaj prometne marginaliziranosti na obrazovanje srednjoškolaca uočavajući postojanje utjecaja vremena putovanja (odnosno lokacije stanovanja) na njihov školski uspjeh. U ostaloj znanstvenoj i stručnoj literaturi utjecaj prometa na život mladih obrađuje se isključivo s aspekta sigurnosti u prometu, ali ne u kontekstu prometne marginaliziranosti. Mali broj radova neizravno se dotiče prometne marginaliziranosti. Šakaja i Višnić (2011) spominju problem nedostatka adekvatne prometne infrastrukture i javnog prijevoza u Karlovcu, što se odražava na poteškoće tijekom provođenja slobodnog vremena mladih. Spevec (2011) razmatra dostupnost i prometnu povezanost kao čimbenike koji utječu na procese migracije i cirkulacije stanovništva sjeverozapadnog dijela Republike Hrvatske.

\section{Prometno marginalizirani prostori}

Značajke mobilnosti i dostupnosti na nekom prostoru, osim o osobnim značajkama stanovništva koje na tom prostoru živi, ovisit će i o samim značajkama prostora. Značajke prostora jesu opseg dostupnih prometnih usluga na tom prostoru te opseg i lokacija aktivnosti kojima ljudi žele pristupiti (Hurni, 2006). One mogu dovesti do prometne marginaliziranosti. Tako će na mobilnost ljudi utjecati nepostojanje javnog prijevoza na nekom prostoru, njegova rijetka frekvencija, nemogućnost da si osoba priušti prometne usluge zbog cijene, lokacija življenja ljudi u odnosu na prometne usluge i željene aktivnosti i slično.
Theoretical

Postulates of

Transport

Disadvantage

Teorijske postavke prometne marginaliziranosti 
HRVATSKI

GEOGRAFSKI

GLASNIK

78/1, 73-95 (2016.)
The easiest way to study transport disadvantaged spaces is through the inter-relationship between space and the public transport system. Considering the lack of public transport as the main characteristics of transport disadvantage of a certain space, transport disadvantaged spaces can be defined as spaces where there is no access to public transport services or there is very limited access to public transport services (Murray and Davis, 2001; Hurni, 2007).

Transport disadvantaged spaces can be perceived within the range of life activities that are accessible for people living in a certain space that people can reach with a certain ease. Here, not only the characteristics of the transport system in the broad sense will play a role, but also spatial features as well as various other factors that do not have personal characteristics. Transport disadvantage can thereby be determined by three elements (Fig. 1):

- residence location (in terms of selection of location of life that people can afford)

- spatial distribution of activities that people want to access (e.g. job, shops...), and

- inadequate level of transport services (e.g. the lack of public transport, poor road infrastructure, etc.).
Najjednostavniji način proučavanja prometno marginaliziranih prostora jest međuodnos prostora i sustava javnog prijevoza. Razmatrajući nepostojanje javnog prijevoza kao glavne karakteristike prometne marginaliziranosti nekog prostora, prometno marginalizirani prostori mogu se definirati kao područja gdje ne postoji ili postoji vrlo ograničen pristup uslugama javnog prijevoza (Murray i Davis, 2001; Hurni, 2007).

Prometno marginalizirani prostori mogu se promatrati u okviru opsega životnih aktivnosti koje su dostupne za stanovništvo koje živi na nekom prostoru i do kojih ljudi mogu s određenom lakoćom doći. Tu će ulogu igrati ne samo obilježja prometnog sustava u širem smislu već i prostorne značajke te razni drugi čimbenici koji nemaju osobna obilježja. Prometnu marginaliziranost pritom mogu određivati tri elementa (sl. 1):

- lokacija stanovanja (u smislu izbora lokacije življenja koju si ljudi mogu priuštiti)

- prostorni raspored aktivnosti kojima ljudi žele pristupiti (rad, trgovina i sl.)

- neadekvatna razina prometnih usluga (nepostojanje javnog prijevoza, loša cestovna infrastruktura i sl.).

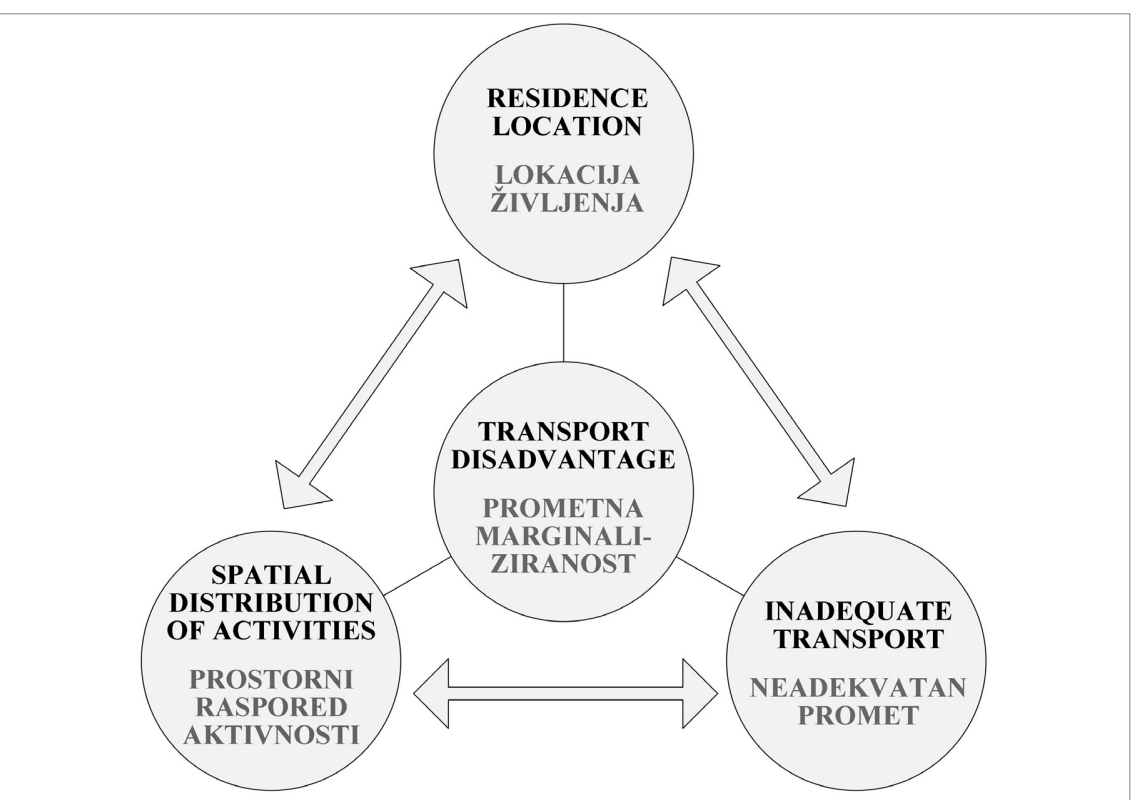

Source: according to Murray and Davis (2001), adapted by the author Izvor: prema Murryju i Davisu (2001), prilagodio autor
Fig. 1 Elements that determine transport disadvantage of certain space

SI. 1. Elementi koji određuju prometnu marginaliziranost nekog prostora 
In this context, transport disadvantaged space can be considered as a space where the degree of accessibility is not high enough to allow unrestricted access to life activities. It should be noted that the possibility of linking people with life's possibilities and opportunities by the transport system will depend on the so-called accessibility parameters. Accessibility parameters can be divided into the following groups (according to Wixey et al., 2005): spatial, temporal, financial, environmental, infrastructural and institutional.

If passengers have to cross long distances to get to the desired location, where the effort of access to sites increases with distance, it is considered a spatial parameter. Spatial parameters include indicators such as the distance of residence location from public transport, routes to the desired locations, etc. (Hurni, 2006).

Temporal parameters refer to spaces in which people cannot get to a location at a specific time (e.g. at night or on weekends when there is no public transport or public transport is very sparse). In general, it can be noted that, in the case of temporal parameters transport supply and transport demand varies over time. Frequency of public transport and its schedule are the main indicators of the temporal parameter of transport disadvantage of space (Currie and Delbosc, 2011b).

Transport expenses that people must pay can be extremely high in some areas, no matter whether mobility it by car or public transport. Therefore, the financial parameter will generally refer to transport costs of particular concessionaires of public transport, amount of fuel consumed, etc. This parameter has a direct effect on the household budgets of families living in these areas (Hurni, 2006).

Spaces exposed to increased noise, polluted air or frequent traffic jams due to the transport, will affect within ecological parameter the transport disadvantage of these spaces. In this process, indicators such as noise, air quality and the like will be used (Currie and Delbosc, 2011b).

The existing transport infrastructure in a space can affect its transport disadvantage if it presents a physical barrier. Motorway or railway lines passing through the space will split the space. A particular
U tom kontekstu prometno marginaliziranim prostorom može se smatrati onaj prostor u kojemu stupanj dostupnosti nije dovoljno visok da omogućuje nesmetan pristup životnim aktivnostima. Pritom valja istaknuti kako će mogućnost da prometni sustav poveže ljude sa životnim mogućnostima i prilikama ovisiti o tzv. parametrima dostupnosti. Parametri dostupnosti mogu se podijeliti u sljedeće skupine (prema Wixey i dr., 2005): prostorni, vremenski, financijski, ekološki, infrastrukturni i institucionalni.

Ako putnici moraju prevaliti veliki put da bi došli do željenih lokacija, pri čemu se trud pristupa lokacijama povećava s udaljenošću, riječ je o prostornom parametru. Prostorni parametar uključuje pokazatelje kao što su udaljenost lokacije življenja od stanica javnog prijevoza, rute kojima se putuje do željenih lokacija itd. (Hurni, 2006).

Vremenski parametar odnosi se na prostore $\mathrm{u}$ kojima ljudi ne mogu doći do određenih lokacija u neko određeno vrijeme (npr. noću ili vikendom ako ne postoji ili je znatno prorijeđen javni prijevoz). Općenito se može kazati kako u slučaju vremenskog parametra prometna ponuda i potražnja variraju tijekom vremena. Frekvencija prometovanja javnog prijevoza i njegov vozni red osnovni su indikatori vremenskog parametra prometne marginaliziranosti prostora (Currie i Delbosc, 2011b).

Prometni troškovi koje ljudi moraju podmirivati mogu na nekim prostorima biti izrazito veliki, bez obzira na to upotrebljava li se za putovanje automobil ili javni prijevoz. Stoga ce se financijski $\mathrm{pa}^{-}$ rametar općenito odnositi na cijene prijevoza kod pojedinoga koncesionara javnog prijevoza, novčani iznos potrošenoga goriva u automobilu itd. Ovaj parametar izravno utječe na kućni budžet obitelji koje žive na takvim prostorima (Hurni, 2006).

Prostori koji su zbog odvijanja prometa izloženi povećanoj buci, onečišćenom zraku ili čestim gužvama, u okviru ekološkog parametra, utjecat će na njihovu prometnu marginaliziranost. Pritom će se upotrebljavati pokazatelji kao što su razina buke, kvaliteta zraka i slično (Currie i Delbosc, 2011b).

Prometna infrastruktura u prostoru može utjecati na njegovu prometnu marginaliziranost ako predstavlja fizičku barijeru. Autocesta ili željeznič-
Theoretical

Postulates of

Transport

Disadvantage

Teorijske postavke prometne marginaliziranosti 
GEOGRAFSKI

GLASNIK

78/1, 73-95 (2016.) problem arises in crossing such routes. If there are few crossings (or passages), and especially if they are not adapted for use of people with disabilities or the elderly, such space within the infrastructure parameter may be characterized as a transport disadvantaged space (Currie and Delbosc, 2011b).

Institutional parameters refer to indicators related to certain institutional decisions relating to transport, by which certain groups of people are placed in a disadvantaged position. Laws and regulations, for example, prohibiting dogs riding in a taxi, will put blind people with guide dogs in an unfavourable position (Currie and Delbosc, 2011b).

\section{Transport disadvantaged groups of people}

If transport disadvantage is investigated from the perspective of inter-dependence of limitations of mobility and accessibility, then the limitations in access to certain activities affecting certain parts of the population can be discussed. Hence, certain social groups will be separated from the society that will be, for certain reasons, more limited in mobility and accessibility, and therefore, in accessing desired activities, and they will be transport disadvantaged by this factor. The contributing factors may vary. Although there is no final or strictly defined list of factors, some of them are more often used in this procedure. Hurni (2006) isolated the following factors: income (financial status), ownership of a vehicle and the ability to drive, gender, age, physical properties of an individual, characteristics of the household, unemployment, knowledge of a language and literacy, ethnicity and migration.

Income, or financial status, affects the ability to afford some form of transport to access the desired activities. People with low incomes will have more problems with the settlement of transport costs compared with those who have higher incomes, regardless of the means of transport. Therefore, such a person will have more problems in access to desired activities, which can be reflected in that person's life in general (e.g. lack of employment opportunities). ka pruga podijelit će prostor kojim prolazi. Poseban problem nastaje kod prijelaza takvih prometnica. Ako prijelaza (ili prolaza) ima malo te posebno ako nisu prilagođeni za osobe s invaliditetom ili starije, takav prostor u okviru infrastrukturnog parametra može biti okarakteriziran kao prometno marginalizirani prostor (Currie i Delbosc, 2011b).

Institucionalni parametar odnosi se na pokazatelje vezane uz određene institucionalne odluke koje se odnose na promet, pri čemu se određene grupe ljudi stavljaju u nepovoljan položaj. Zakoni i pravilnici koji npr. zabranjuju vožnju psima u taksijima stavit će u nepovoljan položaj slijepe osobe s psima vodičima (Currie i Delbosc, 2011b).

\section{Prometno marginalizirane skupine ljudi}

Ako se problematika prometne marginaliziranosti sagledava iz aspekta međuovisnosti ograničenja mobilnosti i prometne dostupnosti, može se govoriti o ograničenjima u pristupu pojedinim aktivnostima koje zahvaćaju određene dijelove populacije. Dakle u društvu se mogu izdvojiti socijalne skupine koje će iz određenih razloga imati veća ograničenja u mobilnosti i dostupnosti, a samim time i u pristupu željenim aktivnostima, odnosno bit će prometno marginalizirane. Čimbenici koji tome pridonose mogu biti različiti. Iako ne postoji konačni i strogo definirani popis čimbenika, neki od njih češće se upotrebljavaju pri tom postupku. Hurni (2006) izdvaja sljedeće čimbenike: prihodi (imovinsko stanje), posjedovanje automobila i mogućnost upravljanja njime, spol, starost, tjelesne karakteristike pojedinca, obilježja kućanstva, (ne)zaposlenost, pismenost (uz znanje jezika) te etnicitet i migracije.

Prihodi, odnosno imovinsko stanje pojedinca, utječu na mogućnost da si osoba priušti korištenje nekim oblikom prometa kako bi pristupila željenim aktivnostima. Ljudi s niskim novčanim primanjima imat ce više problema s podmirivanjem prometnih troškova bez obzira na to o kojem je prometnom sredstvu riječ nego osobe koje imaju veće prihode. Samim time takva će osoba imati više problema u pristupu željenim aktivnostima, što se može odraziti i na njezin cjelokupni život (npr. nemogućnost zapošljavanja). 
If a person owns a car and has the ability to drive it (driving license, no physical limitations), his/her mobility will be almost without limitations. People who are not in such a situation will have significantly limited mobility. In addition, their need for mobility will have to be met by someone else. On the one hand, they will be dependent on someone else (e.g. children on parents), and, on the other, people who meet their mobility needs will have an additional obligation.

Though gender may be a factor contributing to transport disadvantage, some authors have different opinions on this matter. For example, while Hine and Mitchell (2003) consider women as a transport disadvantaged group in society, other authors believe that in this case, gender cannot be considered unequivocally, and instead it should be viewed from the employment standpoint, characteristics of the household, number of children, etc. But the fact remains that in the Republic of Croatia, the number of men holding a driver's license far exceeds the number of women $(1,377,269$ male drivers and 924,194 female drivers) (MUP, 2015). Ultimately, it can place women in a position of dependence on men for driving, or for the need to use other forms of transport. The experiences from some European countries are similar. For example, research in the United Kingdom showed that men are drivers in $48 \%$ of car journeys, and passengers in $17 \%$, while women are drivers in $36 \%$ of car journeys, and passengers in 26\% (DfT, 2011). Certainly, another important fact is that women are exposed more to violence in public transport, which gives an additional argument to their transport disadvantage.

Age as a transport disadvantage factor will especially affect young people. Young people will have significantly limited personal mobility, as long as they do not pass the driving test and begin to drive a car and will depend, with the exception of public transport, on another person in terms of meeting the needs for mobility. Dependence on others in terms of driving results in growing concern of parents for their children's safety, so then the parents drive them to school, extracurricular activities, and to the place where they spend their free time (Johansson, 2006). In addition, personal mobility decreases with age (due to the physical characteristics of a person);
Ako osoba posjeduje automobil i ima mogućnost upravljanja njime (posjeduje vozačku dozvolu i nema tjelesnih ograničenja), njena će mobilnost biti gotovo bez ograničenja. Osobe koje nisu u takvoj situaciji imat će znatno ograničenu mobilnost. Osim toga njihovu potrebu za mobilnošću morat će zadovoljiti netko drugi. S jedne strane, bit će ovisni o nekome (npr. djeca o roditeljima), a s druge strane, osobe koje zadovoljavaju njihovu potrebu za mobilnošću imat će dodatnu obvezu.

Iako spol može biti čimbenik koji pridonosi prometnoj marginaliziranosti, pojedini autori o njemu imaju različito mišljenje. Dok npr. Hine i Mitchell (2003) izdvajaju žene kao prometno marginaliziranu skupinu društva, drugi autori smatraju kako se spol u ovoj problematici ne može uzeti jednoznačno, već ga treba sagledati s aspekta zaposlenosti, obilježja kućanstva, broja djece i slično (Hurni, 2006). No ostaje činjenica kako je, barem u Republici Hrvatskoj, još uvijek znatno veći broj muškaraca s vozačkom dozvolom nego žena (1 377269 muškaraca i 924194 žena) (MUP, 2015). To, u krajnjoj liniji, ženu stavlja u položaj ovisnosti o muškarcu kad je riječ o vožnji ili nameće potrebu korištenja nekim drugim oblikom prijevoza. Slično pokazuju iskustva iz nekih europskih država. Tako je npr. istraživanje u Ujedinjenom Kraljevstvu pokazalo kako $48 \%$ putovanja automobilom muškarci ostvaruju kao vozači, a $17 \%$ kao putnici, dok $36 \%$ putovanja automobilom žene ostvaruju kao vozačice, a $26 \%$ kao putnice (DfT, 2011). Svakako je važna i činjenica da će žena biti izloženija nasilju u javnom prijevozu, što daje dodatni argument njezinoj prometnoj marginaliziranosti.

Starost kao čimbenik prometne marginaliziranosti posebno će utjecati na mlade ljude. Mladima će, sve dok ne polože vozački ispit i ne počnu voziti automobil, osobna mobilnost biti znatno ograničena te će osim o javnom prijevozu ovisiti i o nekoj drugoj osobi u zadovoljavanju potreba za mobilnošću. Ovisnost o drugima u pogledu vožnje rezultat je i sve veće zabrinutosti roditelja za sigurnost svoje djece, pa ih onda voze automobilom u školu, na izvanškolske aktivnosti i na točke odvijanja njihova slobodnog vremena (Johansson, 2006). Također, osobna mobilnost smanjuje se s godinama (zbog tjelesnih značajki osobe) te su i stariji ljudi često
Theoretical

Postulates of

Transport

Disadvantage

Teorijske postavke prometne marginaliziranosti 
GEOGRAFSKI

GLASNIK

78/1, 73-95 (2016.) therefore, older people often depend on others in terms of meeting the needs for mobility.

A person's physical characteristics, in the context of reduced mobility or disability associated with reduced mobility, will affect the possibility of driving a car, will cause problems in the use of public transport and consequently will cause dependence on others. Therefore, the accessibility to desirable activities of such persons will be significantly limited.

The household as a factor in transport disadvantage is characterized by the number of household members. Households with many children, whose needs for mobility to access various activities have to be met, will be significantly disadvantaged, especially if there is only one car in the household or if only one parent has a driver's license.

Generally, unemployed people have low income or financial status. Thus, their mobility will be limited due to reduced possibilities in meeting transport costs. Still, their need for mobility is sometimes heightened by their effort to find work, or possibly attending various courses, retraining, or the like.

Language knowledge and literacy will be the disadvantage of immigrants in particular, who will have limited mobility due to the inability to communicate. This can be manifested in not owning a driver's license or inability to use public transport for these persons because the information is unavailable for them.

Ethnicity and migration will be associated with financial status in the first place. Being part of a certain ethnic community can be the cause of reduced mobility, such as, for example, the generally poor financial status of the Romany minority in Croatia. Immigrants are often of poor financial status, which is then reflected in limited mobility as it would be difficult for them to settle transport costs.

Given that there are no strictly defined factors that determine a transport disadvantaged social groups, some authors distinguish transport disadvantaged social groups based on a variety of factors (Tab. 1). ovisni o drugima u pogledu zadovoljavanja potreba za mobilnošću.

Tjelesne karakteristike pojedinca u okviru smanjene pokretljivosti, odnosno invaliditeta te povezano s time i smanjene mobilnosti utjecat će na nemogućnost upravljanja automobilom, problemima u korištenju javnim prijevozom i ovisnost o drugim osobama. Zbog toga će pristup željenim aktivnostima takvim osobama biti znatno ograničen.

Obilježja kućanstva kao čimbenik prometne marginaliziranosti ogledat će se uglavnom u broju članova. U znatno nepovoljnijoj poziciji bit će kućanstva $s$ većim brojem djece, čije potrebe za mobilnošću i pristup različitim aktivnostima treba zadovoljiti, posebice ako je u kućanstvu samo jedan automobil ili ako samo jedan roditelj ima vozačku dozvolu.

Nezaposleni ljudi u pravilu su i osobe s niskim primanjima odnosno imovinskim statusom. Samim time njihova mobilnost bit će ograničena zbog smanjene mogućnosti podmirivanja prometnih troškova, iako je ponekad njihova potreba za mobilnošću velika upravo zbog traženja posla ili eventualnog pohađanja raznih tečajeva, doškolovanja i slično.

Znanje jezika i pismenost posebno će pogoditi strane doseljenike u neku državu, koji će zbog nemogućnosti sporazumijevanja imati ograničenu mobilnost. To se može očitovati u nemanju vozačke dozvole ili nemogućnosti korištenja javnim prijevozom zbog (tim osobama) nedostupnih informacija.

Etnicitet i migracije u prvom će redu biti povezani s imovinskim statusom. Pripadnost nekoj etničkoj zajednici može utjecati na smanjenu mobilnost, primjerice općenito loše imovinsko stanje romske manjine u Republici Hrvatskoj. Doseljenici, odnosno imigranti često su lošijega imovinskog stanja, što će se odraziti i na ograničenu mobilnost jer će teško moći podmirivati prometne troškove.

Budući da ne postoje strogo definirani čimbenici koji određuju prometno marginalizirane skupine ljudi, pojedini autori na temelju različitih čimbenika izdvajaju prometno marginalizirane socijalne skupine (tab. 1). 
Tab. 1 Transport disadvantaged social groups by selected authors

Tab. 1. Prometno marginalizirane skupine liudi prema odabranim autorima

\begin{tabular}{|c|c|c|c|c|}
\hline & $\begin{array}{l}\text { Hurni } \\
(2006)\end{array}$ & $\begin{array}{l}\text { Currie } \\
(2004)\end{array}$ & $\begin{array}{l}\text { Dodson et al. } \\
\quad(2004)\end{array}$ & $\begin{array}{l}\text { Stanley and } \\
\text { Stanley (2004) }\end{array}$ \\
\hline $\begin{array}{l}\text { Children and youth / } \\
\text { Djeca i mladi }\end{array}$ & & & $\sqrt{ }$ & $\sqrt{ }$ \\
\hline $\begin{array}{l}\text { Ethnic minorities / } \\
\text { Etničke manjine }\end{array}$ & & & $\sqrt{ }$ & \\
\hline $\begin{array}{l}\text { Refugees / asylee / } \\
\text { Izbjeglice / azilanti }\end{array}$ & $\sqrt{ }$ & & & \\
\hline $\begin{array}{l}\text { Unemployed young persons / } \\
\text { Nezaposlene mlade osobe }\end{array}$ & $\sqrt{ }$ & & $\sqrt{ }$ & \\
\hline $\begin{array}{l}\text { Unemployed adult persons / } \\
\text { Nezaposlene odrasle osobe }\end{array}$ & & $\sqrt{ }$ & $\sqrt{ }$ & \\
\hline $\begin{array}{l}\text { Adult persons without a car / } \\
\text { Odrasle osobe bez automobila }\end{array}$ & & $\sqrt{ }$ & & \\
\hline $\begin{array}{l}\text { Low income adult persons / } \\
\text { Odrasle osobe s niskim novčanim primanjima }\end{array}$ & & $\sqrt{ }$ & $\sqrt{ }$ & $\sqrt{ }$ \\
\hline $\begin{array}{l}\text { Disabled persons / } \\
\text { Osobe s invaliditetom }\end{array}$ & $\sqrt{ }$ & $\sqrt{ }$ & $\sqrt{ }$ & $\sqrt{ }$ \\
\hline $\begin{array}{l}\text { Single parents with children / } \\
\text { Samohrani roditelji s djecom }\end{array}$ & $\sqrt{ }$ & & & \\
\hline $\begin{array}{l}\text { Residents of outer urban areas / } \\
\text { Stanovnici izvangradskih prostora }\end{array}$ & & & $\sqrt{ }$ & $\sqrt{ }$ \\
\hline $\begin{array}{l}\text { Older women living alone / } \\
\text { Starije žene koje žive same }\end{array}$ & $\sqrt{ }$ & & & \\
\hline $\begin{array}{l}\text { Older people / } \\
\text { Stariji ljudi }\end{array}$ & & $\sqrt{ }$ & $\sqrt{ }$ & $\sqrt{ }$ \\
\hline $\begin{array}{l}\text { Pupils and students / } \\
\text { Učenici i studenti }\end{array}$ & & $\sqrt{ }$ & & \\
\hline $\begin{array}{l}\text { Women / } \\
\text { Žene }\end{array}$ & & & $\sqrt{ }$ & \\
\hline
\end{tabular}

Source: according to Hurni (2006); Currie (2004); Dodson et al. (2004); Stanley and Stanley (2004), adapted by author Izvor: prema Hurni (2006); Currie (2004); Dodson i dr. (2004); Stanley i Stanley (2004), prilagodio autor

Taking into account the above-mentioned transport disadvantaged social groups referred to by some authors; it is evident that certain social groups are considered extremely transport disadvantaged. For example, people with disabilities and older people are cited as transport disadvantaged by all authors, while adults with low incomes are very often present. Although most of the literature refers to transport disadvantaged groups as groups standing out within the population living in the city (and the city surroundings), some authors believe that transport disadvantage does not have to be present only in town (e.g. Dodson et al., 2004; Stanley and Stanley, 2004).
Theoretical

Postulates of

Transport

Disadvantage

Teorijske postavke prometne marginaliziranosti
S obzirom na navedene prometno marginalizirane skupine društva koje izdvajaju pojedini autori uočljivo je kako se pojedine socijalne skupine smatraju izrazito prometno marginaliziranima. Tako se npr. osobe s invaliditetom i stariji ljudi navode kao prometno marginalizirani kod svih autora, dok su vrlo često prisutne i odrasle osobe s niskim novčanim primanjima. Iako se $u$ većini literature prometno marginalizirane skupine ljudi izdvajaju u okviru populacije koja živi na prostoru grada (i bliže gradske okolice), pojedini autori smatraju kako prometna marginaliziranost ne mora biti prisutna samo $u$ gradu (npr. Dodson i dr., 2004; Stanley i Stanley, 2004). 
It has already been pointed out that one of the main criteria for determining transport disadvantage of certain social groups is owning or ability to use and drive a car (Clifton and Lucas, 2004; Currie and Delbosc, 2011b). Namely, overall, the automobilisation that engulfed the world after World War II led to a dependency of society on the use of a car. A car has become the primary means of transport today. Car transport has become the dominant form of transport, not only over long distances, but also at very short distances. The structure of settlements, particularly cities, is largely adapted to car transport. Spatial growth and development of settlements and related process of suburbanization influenced the use of a car, as it often allows easier access and efficiency in relation to other forms of transport, particularly public transport. According to these facts, certain social groups can be identified that, for any given reason, do not have or have only very limited access to a car or the ability of driving a car, and are thus accordingly transport disadvantaged (Hine and Mitchell, 2003). These reasons are primarily based on the inability to drive a car due to legal restrictions, physical inability, or situations in which a person is not able to afford a car. The fundamental consequence of this is dependence on other people for driving, and reduced accessibility to certain life activities. It should be emphasized that authors tend to use different transport disadvantaged groups of people according to this criterion (Tab. 2). Some will be described in more detail below.

Causes of the transport disadvantage of women are not the same in different societies. It has been mentioned that more men have a driver's license than women. Women are more oriented to use public transport or walking than men (Clifton and $\mathrm{Lu}^{-}$ cas, 2004; Hine and Mitchell, 2003; Hurni, 2006). At world level, women are still more oriented than men to caring for children and carrying out household duties (including doing household shopping and so on.). It is believed that a woman's mobility needs are more complex than a man's (Dowling and Gollner, 1997). In addition, women have more difficulties in finding employment and they rarely get better paid jobs than men. Interaction of all these factors reveals that this situation will lead women into a disadvantageous position compared to men
Već je istaknuto kako je jedan od glavnih kriterija određivanja prometne marginaliziranosti pojedinih skupina ljudi posjedovanje, odnosno mogućnost korištenja i upravljanja automobilom (Clifton i Lucas, 2004; Currie i Delbosc, 2011b). Naime opća automobilizacija koja je zahvatila svijet nakon Drugoga svjetskog rata uzrokovala je ovisnost društva o korištenju automobilom. Automobil je postao neizostavno sredstvo današnjice. Automobilski promet postao je dominantni oblik prometa, i to ne samo na velikim već i na vrlo malim udaljenostima. Struktura naselja, posebice gradova, u velikoj se mjeri prilagodila automobilskom prometu. Prostorni rast i razvoj naselja i s njima povezan proces suburbanizacije utjecali su na korištenje automobilom jer često omogućuje lakšu dostupnost i učinkovitost u odnosu na ostale oblike prometa, posebice javni prijevoz. Sukladno tim činjenicama u društvu se mogu izdvojiti socijalne skupine koje iz određenih razloga nemaju ili imaju vrlo ograničen pristup automobilu, odnosno mogućnost upravljanja automobilom, i koje su prema tome prometno marginalizirane (Hine i Mitchell, 2003). Ti se razlozi uglavnom svode na nemogućnost upravljanja automobilom zbog zakonskih ograničenja, tjelesnih nemogućnosti te situaciju da si osoba nije u mogućnosti priuštiti automobil. Osnovna je posljedica toga njihova ovisnost u određenoj mjeri o drugim osobama glede vožnje i ograničena dostupnost pojedinim životnim aktivnostima. Valja naglasiti kako autori navode različite prometno marginalizirane skupine ljudi prema tom kriteriju (tab. 2). Neke će u nastavku biti detaljnije opisane.

Uzroci prometne marginaliziranosti žena nisu isti u pojedinim društvima. Već je rečeno kako više muškaraca nego žena ima vozačku dozvolu. Pritom su žene više nego muškarci orijentirane na korištenje javnim prijevozom ili pješačenje (Clifton i Lucas, 2004; Hine i Mitchell, 2003; Hurni, 2006). U svjetskim su okvirima žene još uvijek više od muškaraca usmjerene na brigu za djecu i obavljanje kućanskih obveza (što uključuje i odlazak u nabavu i slično) te se smatra kako su ženine potrebe za mobilnošću složenije od muškarčevih (Dowling i Gollner, 1997). Usto, žene se i teže zapošljavaju i teže dobivaju bolje plaćene poslove od muškaraca. Međudjelovanjem svih tih čimbenika može se utvrditi da će takva situacija dovesti ženu u neravnopravan položaj spram muškarca te ograničiti njenu mobil- 
Tab. 2 Transport disadvantaged groups of people by selected authors with respect to (in)ability to drive a car

Tab. 2. Prometno marginalizirane skupine ljudi prema odabranim autorima s obzirom na (ne)mogućnost upravljanja automobilom

\begin{tabular}{|c|c|c|c|c|}
\hline & $\begin{array}{l}\text { Morris } \\
\text { (1981) }\end{array}$ & $\begin{array}{l}\text { Hine and } \\
\text { Mitchell } \\
(2001)\end{array}$ & $\begin{array}{l}\text { Murray and } \\
\text { Davis } \\
(2001)\end{array}$ & $\begin{array}{l}\text { Hurni } \\
\text { (2007) }\end{array}$ \\
\hline $\begin{array}{l}\text { Children and youth / } \\
\text { Djeca i mladi }\end{array}$ & $\sqrt{ }$ & $\sqrt{ }$ & $\sqrt{ }$ & \\
\hline $\begin{array}{l}\text { Immigrants / } \\
\text { Imigranti }\end{array}$ & & & $\sqrt{ }$ & \\
\hline $\begin{array}{l}\text { Low income people / } \\
\text { Ljudi s niskim novčanim primanjima }\end{array}$ & $\sqrt{ }$ & $\sqrt{ }$ & $\sqrt{ }$ & \\
\hline $\begin{array}{l}\text { Unemployed young persons / } \\
\text { Nezaposlene mlade osobe }\end{array}$ & & & & $\sqrt{ }$ \\
\hline $\begin{array}{l}\text { Disabled persons / } \\
\text { Osobe s invaliditetom }\end{array}$ & $\sqrt{ }$ & $\sqrt{ }$ & $\sqrt{ }$ & \\
\hline $\begin{array}{l}\text { Single parents / } \\
\text { Samohrani roditelji }\end{array}$ & & & & $\sqrt{ }$ \\
\hline $\begin{array}{l}\text { Older people / } \\
\text { Stariji ljudi }\end{array}$ & $\sqrt{ }$ & $\sqrt{ }$ & $\sqrt{ }$ & \\
\hline $\begin{array}{l}\text { Multiple member households / } \\
\text { Višečlana kućanstva }\end{array}$ & & & $\sqrt{ }$ & \\
\hline $\begin{array}{l}\text { Multiple family households / } \\
\text { Višeobiteljska kućanstva }\end{array}$ & & & $\sqrt{ }$ & \\
\hline $\begin{array}{l}\text { Women / } \\
\text { Žene }\end{array}$ & & $\sqrt{ }$ & & \\
\hline
\end{tabular}

Theoretical

Postulates of

Transport

Disadvantage

Teorijske postavke prometne marginaliziranosti

Source: according to Morris (1981); Hine and Mitchell (2001); Murray and Davis (2001); Hurni (2007), adapted by author Izvor: prema Morris (1981); Hine i Mitchell (2001); Murray i Davis (2001); Hurni (2007), prilagodio autor

and will limit their mobility, and thus their accessibility of desired activities. Certainly there is a difference in transport disadvantage within this social group. Thus, single mothers, older women, women with disabilities, etc., will be especially exposed to transport disadvantage (Hine and Mitchell, 2003).

Because of their physical characteristics and lower income than the employed population, older people have fewer opportunities to drive a car. Thus, their mobility will be limited. Therefore, older people will use much more public transport or walking as a mode of transport (Hine and Mitchell, 2003). Because of reduced mobility, older people often rely on help from family members or other people, thus, putting persons who help them in an unfavourable position (Clifton and Lucas, 2004). To ensure a better quality of life for older people, there should increase in the possibilities for their mobility. Care should be taken to adapt the infrastructure forms of transport they use. Adjusting the sidewalks and nost, a time i dostupnost željenim aktivnostima. Svakako pritom postoji i razlika u prometnoj marginaliziranosti unutar te socijalne skupine. Tako će prometnoj marginaliziranosti posebno biti izložene samohrane majke, starije žene, žene s invaliditetom itd. (Hine i Mitchell, 2003).

Stariji ljudi zbog svojih fizičkih karakteristika i nešto nižih novčanih primanja od zaposlenog stanovništva imaju manje mogućnosti za upravljanje automobilom. Time će i njihova mobilnost biti ograničena. Zbog toga će se stariji ljudi znatno više koristiti javnim prijevozom ili pješačenjem kao oblikom prometa (Hine i Mitchell, 2003). Stariji se ljudi zbog smanjene mobilnosti često oslanjaju i na pomoć obitelji ili drugih osoba, čime stavljaju u nepovoljan položaj osobe koje im pomažu (Clifton i Lucas, 2004). Da bi se osigurala bolja kvaliteta života starijih ljudi, treba povećati i mogućnosti za njihovu mobilnost. Pritom valja voditi računa da infrastruktura oblika prometa kojim se oni koriste bude njima 
GEOGRAFSKI

GLASNIK

78/1, 73-95 (2016.) pedestrian paths, stairs and handrails in pedestrian transport, and the introduction of low-floor transport vehicles in public transport are just some of the possible solutions.

The vast majority of people with disabilities have significantly limited mobility, so they are directly disadvantaged, also in accessing desired activities. Due to physical problems, many of them are not able to drive a car and are limited to using public transport or to walking. In these modes of transport, they face significant difficulties (e.g. difficulties in moving through the streets because of improperly parked cars, difficult using public transportation, especially in terms of entering and exiting the vehicle unless they are low-floor, etc.). It is also important to note that people with disabilities travel much less and cross considerably lower distances than other people, because of significantly limited mobility (Hine and Mitchell, 2003).

\section{The consequences of transport disadvantage}

Persons affected by transport disadvantage (in any form) will be in a less favourable position in comparison to transport non-disadvantaged people. This less favourable position pertains to limitations or exclusion concerning participation in activities or the use of certain services.

Transport disadvantage can be a significant barrier to accessing or finding a job. Research has shown that people living on the outskirts of the city or in rural areas have more problems if they do not have access to a car, usually with a poorer level of public transport service in these areas (Hine and Mitchell, 2001; 2003). At the same time, the phenomenon of the relocation of people occurs due to the possibility of employment or work in order to better exploit travel time (Levinson and Kumar, 1994). Further, problems occur with locations where new activities appear (e.g. planning new business zones), which are not adequately covered by transport services (e.g. poor frequency of public transport or absence of public transport). Therefore, such activities will be difficult to carry out for those people who are not able to drive a car. Poor transport accessibility and the lack of transport possibilities will affect oppor- prilagođena. Prilagođavanje nogostupa i pješačkih staza, stuba, rukohvata kod pješačkog prometa te uvođenje niskopodnih prijevoznih sredstava u javnom prijevozu samo su neka od mogućih rješenja.

Velikoj većini osoba s invaliditetom mobilnost je znatno ograničena, čime su izravno zakinuti i za pristup željenim aktivnostima. Mnogi od njih zbog tjelesnih poteškoća ne mogu upravljati automobilom te su ograničeni na korištenje javnim prijevozom ili pješačenje. No i kod tih oblika prometa nailaze na velike poteškoće (npr. u kretanju ulicama zbog nepropisno parkiranih automobila, korištenje javnim prijevozom otežano im je, posebice u smislu ulaska u vozilo i izlaska iz njega nije niskopodno i slično). Također je važno napomenuti kako osobe s invaliditetom i znatno manje putuju i prelaze znatno manje udaljenosti od ostalih ljudi, upravo zbog uvelike ograničene mobilnosti (Hine i Mitchell, 2003).

\section{Posljedice prometne marginaliziranosti}

Osobe zahvaćene prometnom marginaliziranošću (u bilo kojem obliku) bit će u nepovoljnijem položaju u odnosu na prometno nemarginalizirane osobe. Taj se položaj odnosi uglavnom na prepreke ili isključenost spram sudjelovanja u nekim aktivnostima ili korištenja određenim uslugama.

Prometna marginaliziranost može biti znatna prepreka u pristupu poslu odnosno pronalaženju posla. Istraživanja pokazuju kako će veće probleme imati osobe koje žive na rubu grada ili u ruralnim prostorima ako nemaju pristup automobilu, uz obično lošiju razinu usluge javnog prijevoza u tim prostorima (Hine i Mitchel, 2001; 2003). Pritom se javlja i pojava preseljenja ljudi radi mogućnosti zaposlenja ili obavljanja posla kako bi se bolje iskoristilo vrijeme putovanja (Levinson i Kumar, 1994). Problem su i lokacije na kojima se javljaju novi poslovi (npr. uređenje novih poslovnih zona), a koje nisu adekvatno pokrivene prometnim uslugama (primjerice nedovoljna frekvencija ili nepostojanje javnog prijevoza), zbog čega će takve poslove teško moći obavljati osobe koje nisu u mogućnosti upravljati automobilom. Loša prometna dostupnost i nedostatak prometnih mogućnosti utjecat ce na 
tunities for employment and entire areas inhabited by unemployed people will emerge. These are largely areas with a poor level of public transport services and, therefore, people are often forced to have their own car. Ultimately, this leads to increased transport costs associated with fuel consumption and maintenance of the car (Hine and Mitchell, 2003; Currie, 2007).

In regard to problems in accessing certain life functions, it is necessary to emphasize the limitation of participation in educational activities. Young people will be especially affected by this problem. Namely, young people living at the city periphery or rural areas will have fewer opportunities to participate in extracurricular activities due to greater distance and poor transport service organisation. For that reason, these young people lose opportunities for additional education. The selection of a high school to attend also depends in part on the level of transport services and the distance from home to school. Namely, in some countries, there are differences in the percentage of high school attendees between youth living at the city periphery and youth living in the city. Young people living far from school will have less time for studying and less free time than those young people who spend less time travelling to and from school (Gašparović, 2014). The level of transport services in the area of living and distance to schools affects the decision to continue higher education. Youth from urban areas are more likely to enrol in university than youth from rural regions. In addition, problems concerning limited participation in educational activities will also be experienced by other transport disadvantaged groups, particularly persons with disabilities (Winter, 1994; Currie, 2007; Hurni, 2007).

Transport disadvantage may lead to problems in accessing different types of services (e.g. doctor, bank or store) as well as restricted access to leisure activities (e.g. recreation or evening outings). Limited possibilities of evening outings, as well as going to the cinema, theatre or museums will negatively affect social interaction of transport disadvantaged people and their overall social life. Thereby, people living in the city periphery or in rural areas will experience more restrictions (Winter, 1994; Hurni 2006). nezaposlenost i stvaranje čitavih područja u kojima žive nezaposleni ljudi. Uglavnom su to prostori koji vrlo često imaju lošu razinu usluga javnog prijevoza, te su ljudi često prisiljeni imati vlastiti automobil. U konačnici to dovodi do povećanih prometnih troškova povezanih s potrošnjom goriva i održavanjem automobila (Hine i Mitchell, 2003; Currie, 2007).

U kontekstu problema s pristupom pojedinim životnim funkcijama valja posebno naglasiti ograničenje sudjelovanja u obrazovnim aktivnostima. Tim će problemom posebno biti pogođeni mladi ljudi. Naime mladi koji žive na gradskoj periferiji ili u ruralnom prostoru zbog veće udaljenosti koju moraju prijeći te slabije razvijenih prometnih usluga imat će manje mogućnosti sudjelovanja u izvanškolskim aktivnostima. Samim time mladi mogu propustiti priliku za dodatno obrazovanje. Odabir srednje škole koju će pohađati također donekle ovisi i o razini prometnih usluga odnosno o udaljenosti od same škole. Naime u pojedinim državama uočava se razlika u postotku pohađanja srednje škole između mladih koji žive na rubu grada i mladih iz samoga grada. Putovanje do škole i obratno utjecat će na raspoloživo vrijeme za učenje i slobodno vrijeme. Mladi koji žive daleko od škole imat će manje vremena za učenje i slobodnog vremena od mladih koji troše malo vremena na put do škole (Gašparović, 2014). Razina prometnih usluga na prostoru gdje žive i udaljenost mogu utjecati na odluku o nastavljanju visokoškolskog obrazovanja kod mladih. Mladi iz urbanih prostora češće će upisati fakultet od mladih iz ruralnih krajeva. No probleme s ograničenjem sudjelovanja u obrazovnim aktivnostima iskusit će i ostale prometno marginalizirane grupe ljudi, posebice osobe s invaliditetom (Winter, 1994; Currie, 2007; Hurni, 2007).

Prometna marginaliziranost može dovesti i do problema u pristupu različitim vrstama usluga (npr. liječnika, banke ili trgovine) kao i do ograničenja pristupa aktivnostima slobodnog vremena (npr. rekreacija ili večernji izlasci). Ograničena mogućnost večernjih izlazaka, ali i odlaska u kino, kazalište ili muzeje negativno će utjecati na socijalne interakcije zahvaćenih prometnom marginaliziranošću, odnosno na njihov cjelokupni društveni život. Pritom će veća ograničenja doživjeti osobe koje žive na gradskom rubu ili u ruralnim prostorima (Winter, 1994; Hurni 2006).
Theoretical

Postulates of

Transport

Disadvantage

Teorijske postavke prometne marginaliziranosti 
Transport disadvantage is closely related to the perception of safety and fear in transport and, therefore, affect the mobility of these people. Thus, older people, women and members of ethnic minorities feel more fear in public transportation than the rest of the population. Similarly, women often feel more fear than men when using public transport. This fear is especially expressed during transport at night. Therefore, members of these social groups often use alternative transport solutions if there is a fear of riding in public transportation (e.g. personal car and taxi or avoiding travel), which leads to problems in the organization of everyday life (Hine and Scott, 2000; Hine and Mitchell, 2001; Hine and Mitchell, 2003).

Longer periods of an individual's unemployment, poor financial status and social isolation are processes that often interact with each other and lead to social exclusion (Šverko et al., 2006). Transport disadvantage can cause further deterioration of such conditions. Transport disadvantage as the process of mobility and accessibility limitation will cause restriction of access to social and economic activities, which leads to reduced quality of life and further social exclusion of the individual. This is reflected in limiting access to employment, exclusion from the use of services, enhancing fear and feelings of insecurity in transport, reduced educational opportunities, etc. (SEU, 2003; Delbosc and Currie, 2011; 2011b). The lack of adequate, accessible and affordable transport services will be an important restriction to participation of different social groups in the everyday life of society. Again, the importance of access to a car should be emphasized because its inaccessibility can cause difficult access to employment, educational opportunities, health and other services and recreational activities (Hurni, 2006).

\section{Conclusion}

In the real world it is difficult to separate transport disadvantaged persons from transport disadvantaged spaces. Factors causing the two phenomena are mostly intertwined and are not unambiguous. In this respect, there is a certain critical approach on the part of some authors. Although certain so-
Prometna marginaliziranost u uskoj je vezi s percepcijom sigurnosti i straha u prometu, što će utjecati na mobilnost tih osoba. Tako stariji ljudi, žene i pripadnici etničkih manjina osjećaju veći strah u javnom prijevozu od ostatka populacije. Slično tome, u žena je strah prilikom korištenja javnim prijevozom često veći nego u muškaraca. Taj je strah posebice izražen tijekom noćnih vožnji. Zbog njega se pripadnici tih socijalnih skupina često koriste drugim rješenjima u prijevozu (npr. osobno vozilo i taksi ili izbjegavanje putovanja), što dovodi do problema u organizaciji svakodnevnog života (Hine i Scott, 2000; Hine i Mitchell, 2001, 2003).

Duža nezaposlenost pojedinca, njegovo loše imovinsko stanje i socijalna izolacija procesi su koji često u međusobnoj interakciji dovode do socijalne isključenosti (Šverko i dr., 2006). Dodatno pogoršanje takva stanja može uzrokovati prometna marginaliziranost. Ona će kao proces ograničenja mobilnosti i dostupnosti utjecati na ograničenje pristupa socijalnim i ekonomskim aktivnostima, čime smanjuje kvalitetu života i dodatno pojačava socijalnu isključenost pojedinca. To se ogleda u ograničavanju pristupa zaposlenju, isključenosti spram korištenja uslugama, pojačavanju straha i osjećaja nesigurnosti u prometu, smanjenim obrazovnim prilikama i slično (SEU, 2003; Delbosc i Currie, 2011a; 2011b). Nedostatak primjerenih, dostupnih i financijski pristupačnih prometnih usluga bit će vrlo značajno ograničenje u sudjelovanju različitih društvenih grupa u svakodnevnom životu društva. Pritom se ponovno može istaknuti važnost pristupa automobilu jer njegova nedostupnost može utjecati na otežani pristup zaposlenju, obrazovnim mogućnostima, zdravstvenim i drugim uslugama te rekreacijskim aktivnostima (Hurni, 2006).

\section{Zaključak}

U realnom svijetu teško je odvojeno promatrati prometno marginalizirane osobe od prometno marginaliziranih prostora. Čimbenici koji uzrokuju te dvije pojave uglavnom su isprepleteni i nisu jednoznačni. U tom smislu postoji i određeni kritički pristup pojedinih autora. Iako se određene 
cial groups are referred as transport disadvantaged in their entirety, it is notable that social groups in most of its features are not homogeneous. In the context of transport disadvantage, this is particularly evident in the heterogeneity of features such as financial status and pattern of activities, which will affect the mobility, transport needs and desired activity that a person wants to access. Also, the reasons why individuals are transport disadvantaged are generally multidimensional. Moreover, when considering the transport disadvantage of certain social groups, often only certain personal characteristics are taken into account, such as age, which does not fully reveal the relationship with other socio-economic factors. Finally, considerations rarely take into account a broader geographical context, for example, the inter-relationship between living locations, locations of activities that people want to join and the needs of the people and their ability to move between these locations.

Therefore, Lucas (2004b) believes that it is necessary to include as many parameters as possible and observe transport disadvantage within a multidimensional process through three interrelated groups of factors: people living in a particular space (age, gender, ethnicity, household characteristics and financial status having crucial importance), the characteristics of the space in which these people live (type of settlement, topographic features, the crime rate and the development of infrastructure) and transport characteristics (with particular emphasis on the form of transport that people use, the accessibility of certain types of transport in terms of use, the suitability of certain forms transport to use, costs that must be settled and available transport information).

Finally, transport disadvantage today is a ubiquitous process that can affect people and spaces. Its consequences can be extremely negative as it leads to restrictions on access to life opportunities and possibilities and to participation in various forms of social activities, which can lead to social inequalities. Transport disadvantage can ultimately lead to social exclusion. For all these reasons, there is a need for detecting transport disadvantaged groups of people and spaces, as well as for studying the impact of transport disadvantage on people's daily socijalne skupine spominju kao prometno marginalizirane u svojoj cjelovitosti, valja istaknuti kako socijalne skupine u većini svojih obilježja nisu homogene. U kontekstu prometne marginaliziranosti to se posebno očituje u heterogenosti značajki kao što su imovinski status i obrazac aktivnosti, što će utjecati na mobilnost, prometne potrebe i željene aktivnosti kojima osoba želi pristupiti. Također, razlozi prometne marginaliziranosti pojedinaca uglavnom su multidimenzionalni. Osim toga pri razmatranju prometne marginaliziranosti pojedinih socijalnih skupina u obzir se često uzima samo pojedina osobna značajka, primjerice dob, što ne mora u potpunosti prikazati odnos s ostalim socioekonomskim čimbenicima. I na kraju, razmatranja rijetko uzimaju u obzir širi geografski kontekst, kao što su međuodnos lokacije življenja, lokacije aktivnosti kojima ljudi žele pristupiti te potreba ljudi i njihove mogućnosti kretanja između tih lokacija.

Stoga Lucas (2004b) smatra kako je potrebno uključiti što je moguće više parametara i prometnu marginaliziranost promatrati u okviru multidimenzionalnog procesa kroz tri međusobno povezane skupine čimbenika: ljude koji žive na nekom prostoru (presudnu će važnost imati starost, spol, etnicitet, obilježja kućanstva i imovinski status), obilježja prostora na kojima ti ljudi žive (tip naselja, topografske značajke, stopa kriminaliteta i razvijenost infrastrukture) i prometne značajke (s posebnim naglaskom na oblik prometa kojim se ljudi koriste, dostupnost pojedinih oblika prometa u smislu mogućnosti korištenja njime, prikladnost pojedinih oblika prometa za korištenje, troškove koje valja podmiriti i dostupne prometne informacije).

$\mathrm{Na}$ kraju, prometna marginaliziranost danas je sveprisutan proces koji može zahvatiti i ljude i prostore. Njene posljedice mogu biti izrazito negativne jer dolazi do ograničavanja pristupa životnim prilikama i mogućnostima te participiranja u različitim oblicima društvenih aktivnosti, što može dovesti do socijalne nejednakosti. Prometna marginaliziranost u konačnici može uzrokovati socijalnu isključenost. Zbog svega toga postoji potreba za detektiranjem prometno marginaliziranih skupina ljudi i prostora, kao i za proučavanjem utjecaja prometne margina-
Theoretical

Postulates of

Transport

Disadvantage

Teorijske postavke prometne marginaliziranosti 
lives and spatial development. Moreover, particular attention should be paid to the more efficient problem-solving of transport disadvantage within properly conducted social policy and transport planning. liziranosti na svakodnevni život ljudi te na prostorni razvoj. Osim toga valja posebno obratiti pozornost na što učinkovitije rješavanje problema prometne marginaliziranosti u okviru ispravno vođene socijalne politike i prometnog planiranja.

\section{Literature} Literatura
Battelino, H., 2009: Transport for the transport disadvantaged: A review of service delivery solutions in New South Wales, Transport Policy 16 (3), 123-129.

Black, W. R., 2003: Transportation. A geographical analysis, The Guilford Press, New York.

Church, A., Frost, M., Sullivan, K., 2000: Transport and Social Exclusion in London, Transport Policy 7 (3), 195-205.

Clifton, K., Lucas, K., 2004: Examining the empirical evidence of transport inequality in the US and UK, in: Running on empty: Transport, social exclusion and environmental justice (ed. Lucas, K.), The Policy Press, Bristol, 15-36.

Currie, G., 2007: Young Australians: No Way to Go, in: No Way To Go - Transport and Social Disadvantage in Australian Communities (eds. Currie, G., Stanley, J., Stanley, J.), Monash University ePress, Clayton, 08.1.-08.14.

Currie, G., Richardson, T., Smyth, P., Vella-Brodrick, D., Hine, J., Lucas, K. Stanley, J., Morris, J., Kinnear, R., \& Stanley, J., 2009: Investigating links between transport disadvantage, social exclusion and well-being in Melbourne - Preliminary results, Transport Policy 16 (3), 97-105.

Currie, G., Delbosc, A., 2010: Modelling the social and psychological impacts of transport disadvantage, Transportation 37 (6), 953-966.

Currie, G., Delbosc, A., 2011a: Exploring transport issues, in: New Perspectives and Methods in Transport and Social Exclusion Research (ed. Currie, G.), Emerald Group Publishing Limited, Bingley, 111-122.

Currie, G., Delbosc, A., 2011b: Transport Disadvantage: A Review, in: New Perspectives and Methods in Transport and Social Exclusion Research (ed. Currie, G.), Emerald Group Publishing Limited, Bingley, 15-25.

Delbosc, A., Currie, G., 2011a: Exploring the Relative Influences of Transport Disadvantage and Social Exclusion on Well-being, Transport Policy 18 (4), 555562 .
Delbosc, A., Currie, G., 2011b: The Spatial Context of Transport Disadvantage, Social Exclusion and Well-being, Journal of Transport Geography 19 (6), 1130-1137.

Delbosc, A., Currie, G., 2011c: Transport problems that matter - social and psychological links to transport disadvantage, Journal of Transport Geography, 19 (1), 170-178.

Delbosc, A., Currie, G., 2012: Choice and disadvantage in low-car ownership households, Transport Policy 23 (1), 8-14.

Denmark, D., 1998: The Outsiders: Planning and Transport Disadvantage, Journal of Planning Education and Research 17 (3), 231-245.

Department for Transport (DfT), 2011: National Travel Survey 2010, https:// www.gov.uk/government/uploads/ system/uploads/attachment_data/ file/8932/nts2010-01.pdf (10. 08. 2015.)

Dijst, M., 1999: Two-earner families and their action spaces: a case study of two Dutch communities, GeoJournal 48 (3), 195-206.

Dodson, J., Gleeson, B., Sipe, N., 2004: Transport Disadvantage and Social Status: a review of literature and methods No. 5, Griffith University, Brisbane.

Dowling, R., Gollner, A., 1997: Women and transport: from disadvantage to mobility through the automobile, 21st Australasian Transport Research Forum, Adelaide, http://www.atrf.info/papers/1997/ (06. 06. 2015.)

Foley, J., 2004: Overview, in: Sustainability and social justice (ed: Foley, J.), Institute for Public Policy Research, London, 1-12.

Gašparović, S., 2014: Impact of transport disadvantage on education of high school population of the City of Zagreb, in: Proceedings of the Second International Conference on Traffic and Transport Engineering ICTTE Belgrade 2014 (ed. Čokorilo, O.), City Net Scientific Research Center, Belgrade, 789-800.

Gašparović, S., Jakovčić, M., 2014: Promet- na marginaliziranost na primjeru srednjoškolaca Grada Zagreba/Transport disadvantage: the example of high school population in the City of Zagreb, Geoadria 19 (1), 61-99.

Hine, J., Mitchell, F., 2001: The Role of Transport in Social Exclusion in Urban Scotland, Scottish Executive Central Research Unit, Edinburgh.

Hine, J., Mitchell, F., 2003: Transport Disadvantage and Social Exclusion: Exclusionary Mechanisms in Transport in Urban Scotland, Ashgate, Surrey, Burlington.

Hine, J., Scott, J., 2000: Seamless, accessible travel: users'views of the public transport journey and interchange, Transport Policy 7 (3), 217-226.

Hoyle, B., Knowles, R., 1998: Transport geography: An introduction, in: Modern Transport Geography, Second revised edition (eds. Hoyle, B., Knowles, R.), John Wiley \& Sons, Chichester, 1-12.

Hurni, A., 2006: Transport and Social Disadvantage in Western Sydney: A Partnership Research Project, University of Western Sydney and Western Sydney Community Forum, Sydney.

Hurni, A., 2007: Marginalised groups in Western Sydney: The experience of sole parents and unemployed young people, in: No Way To Go - Transport and Social Disadvantage in Australian Communities (eds. Currie, G., Stanley, J., Stanley, J.), Monash University ePress, Clayton., 10.1.-10.11.

Johansson, M., 2006: Environment and parental factors as determinants of mode for children's leisure travel, Journal of Environmental Psychology 26 (2), 156-169.

Kamruzzaman, Md., Hine, J., 2011: Participation index: a measure to identify rural transport disadvantage?, Journal of Transport Geography 19 (4), 882-899.

Kamruzzaman, Md., Hine, J., 2012: Analysis of rural activity spaces and transport disadvantage using a multi-method approach, Transport Policy 19 (1), 105-120

Knowles, R., Shaw, J., Docherty, I., 2008: Transport geographies: Mobilities, flows 
and spaces, Blackwell Publishing Ltd, Morris, J., 1981: Urban Public TransMalden, Oxford, Carlton.

Levinson, D., Kumar, A., 1994: The Rational Locator: Why Travel Times Have Remained Stable, Journal of the American Planning Association 60 (3), 319-332.

Lucas, K., 2004a: Locating transport as a social policy problem, in: Running on empty: Transport, social exclusion and environmental justice (ed. Lucas, K.), The Policy Press, Bristol, 7-13.

Lucas, K., 2004b: Transport and social exclusion, in: Running on empty: Transport, social exclusion and environmental justice (ed. Lucas, K.), The Policy Press, Bristol, 39-53.

Ministarstvo unutarnjih poslova Republike Hrvatske (MUP), 2015: Bilten o sigurnosti cestovnog prometa, Ministarstvo unutarnjih poslova, Zagreb.

Minogue, K., 1998: Social justice in theory and practice, in: Social justice: from Hume to Walzer (eds. Boucher, D., Kelly, P.), Routledge, London, 253-266. port, in: Equity in the City (ed. Troy, P.) George Allen \& Unwin, Sydney, 21-49.

Murray, A. T., Davis, R., 2001: Equity in regional service provision, Journal of $R e-$ gional Science 41, 577-600.

Rosier, K., McDonald, M., 2011: The relationship between transport and disadvantage in Australia, Australian Institute of Family Studies, Melbourne.

Social Exclusion Unit, 2003: Making the Connections: Final Report on Transport and Social Exclusion, Office of the Deputy Prime Minister, United Kingdom

Spevec, D., 2011: Prostorne značajke demografskih resursa i potencijala Krapinsko-zagorske, Varaždinske i Međimurske županije, Hrvatsko geografsko društvo, Zagreb.

Stanley, J., Stanley, J., 2004: Improving Public Transport to meet Community Needs: A Warrnambool Case-study, Bus Association Victoria and Warrnambool Bus Lines, Melbourne.
Šakaja, L., Višnić, S., 2011: Experiencing a Place: Karlovac as an Older Teenagers' Daily Environment, Hrvatski geografski glasnik 73 (1), 133-148

Šverko, B., Galić, Z., Maslić Seršić, D., 2006: Nezaposlenost i socijalna isključenost: longitudinalna studija, Revija za socijalnu politiku 13 (1), 1-14.

Winter, I., 1994: Young People Living on the Urban Fringe, Family Matters 38, 43-45.

Wixey, S., Jones, P., Lucas, K., Aldridge, M., 2005: Measuring accessibility as experienced by different socially disadvantaged groups, London, Transit Studies Group, University of Westminster.

Yigitcanlar, T., Kushairi, R., Dur, F., 2010: Sustainable Urban and Transport Development for Transportation Disadvantaged: A Review, The Open Transportation Journal 4, 1-8.
Theoretical

Postulates of

Transport

Disadvantage

Teorijske postavke prometne marginaliziranosti 